\title{
PYGMY SPERM WHALE (KOGIA BREVICEPS) STRANDING RECORD IN TASMANIA, AUSTRALIA, AND DIET OF A SINGLE SPECIMEN
}

\author{
by Isabel Beasley, Yves Cherel, Sue Robinson, Emma Betty and Rosemary Gales \\ (with two text-figures, one plate, three tables and an appendix)
}

\begin{abstract}
Beasley, I., Cherel, Y., Robinson, S., Betty, E. \& Gales, R. 2013 (17:xii): Pygmy Sperm Whale (Kogia breviceps) stranding record in Tasmania, Australia, and diet of a single specimen. Papers and Proceedings of the Royal Society of Tasmania 147: 25-32. https://doi.org/10.26749/rstpp.147.25 ISSN 0080-4703. School of Earth and Environmental Sciences, James Cook University, Townsville, Queensland 4811, Australia (IB*); Centre d'Etudes Biologiques de Chizé, France (YC); Invasive Species Branch, Department of Primary Industries, Parks, Water and Environment, GPO Box 44 Hobart, Tasmania 7001, Australia (SR); Institute for Applied Ecology New Zealand, School of Applied Sciences, Auckland University of Technology, New Zealand (EB); Biodiversity Conservation Branch, Department of Primary Industries, Parks, Water and Environment, GPO Box 44 Hobart, Tasmania, 7001 Australia (RG).*Author for correspondence. Email: Isabel.Beasley@jcu.edu.au
\end{abstract}

This study describes the stranding record of the Pygmy Sperm Whale, Kogia breviceps, in Tasmanian waters, and the diet of a single individual. The Pygmy Sperm Whale is one of the most commonly stranded cetaceans in some parts of Australia, although it occurs infrequently in the Tasmanian stranding record, with only seven known stranding events. Dietary items were investigated from a single juvenile male Pygmy Sperm Whale stranded in southeast Tasmania. The recoverable diet consisted of approximately three kilograms of reconstructed cephalopod prey mass from at least 11 cephalopod species within nine families. Using reconstructed biomass, the most important family was Histioteuthidae (Histioteuthis atlantica and H. miranda: 29\% of reconstructed biomass), followed by Ommastrephidae (unknown sp.: 27\% of reconstructed biomass), Enoploteuthidae (Enoploteuthis sp): 25\% of reconstructed biomass), Cranchiidae (Cranchia scabra and Teuthowenia pellucida), Chiroteuthidae (Chiroteuthis veranyi), Brachioteuthidae (Brachioteuthis linkovskyi), Neoteuthidae (Nototeuthis dimegacotyle), Pyroteuthidae (Pyroteuthis margaritifera) and Sepiolidae (Heteroteuthis sp.). Collection and analysis of biological material from Pygmy Sperm Whale strandings around Australia should be a high priority to better understand the ecology of this poorly known species. Key Words: Pygmy Sperm Whale, Kogia breviceps, diet, cephalopods, Tasmania, Australia.

\section{INTRODUCTION}

The Pygmy Sperm Whale, Kogia breviceps (Blainville, 1838) is one of the least understood of all cetaceans that frequent Australian waters. This oceanic species is widely distributed in tropical and temperate waters of the Atlantic, Pacific and Indian oceans (McAlpine 2002); however, it is elusive and rarely sighted at sea.

There are only two known reported sightings of Pygmy Sperm Whales in Australian waters (DEWHA 2011), so that much of what is known about the occurrence of this small cetacean is obtained through stranding records. Stranded Pygmy Sperm Whales have been recorded from all Australian states but not the Northern Territory, with 24 stranding events (up to 2011) reported from Queensland (Strandnet, Department of Environment and Heritage Protection, records from 1932-2011); 16 strandings (up to 2008) reported from Victoria (K. Greengrass, Department of Sustainability and Environment, pers. comm.); 40 stranding events reported from South Australia (Kemper \& Ling 1991, Kemper unpubl. data); and 18 strandings (from 1981-2010) recorded from Western Australia (Groom \& Coughran 2012). No information was available for New South Wales.

Despite these strandings, few published data exist regarding Pygmy Sperm Whale morphometrics, biology or diet from Australian waters. Information on Pygmy Sperm Whale diet is available from only three studies in the Australian/Tasman region: Hale (1947) and Plön (2004) in Australia and Beatson (2007) in New Zealand. Hale (1947) described fragments of prawns from the genera Peneus (Family Peneidae) and Hymenodora (Family Oplophoridae) obtained from the stomach of an adult female that stranded at Port Victoria in 1937, and several cephalopod beaks (Sepioteuthis australis Quoy \& Gaimard, 1832) from the stomach of her calf, which was apparently also still suckling. Plön (2004) investigated the natural history of Kogia sp. off Southern Africa, where samples from four South Australian animals were compared to Southern Africa animals. Plön (2004) found remains of the crustacean Neognathauphausia ingens Dohrn, 1870, as well as large quantities of Octopodidae, Enoploteuthidae, Histioteuthidae and Ommastrephidae (i.e., >20\% mass/ individual), and smaller quantities of Chiroteuthidae, Octopoteuthidae, Ommastrephidae and Mastigoteuthidae (i.e., <20\% mass/individual). Beatson (2007) investigated Pygmy Sperm Whale diet from 27 stranded individuals in New Zealand, where Pygmy Sperm Whales are one of the most frequently stranded cetacean species. Beatson (2007) found that the diet consisted primarily of mesopelagic cephalopods (23 species from 13 families, dominated by juvenile individuals of the families Histioteuthidae and Cranchiidae), with some fish and crustacean remains also present.

Investigations of diet are particularly important for cetacean species not commonly observed at sea, such as the Pygmy Sperm Whale. Dietary information can assist in determining habitat use, foraging behaviour, preferred prey, and in assessing any direct or indirect interactions with fishery operations. This study presents the first detailed qualitative and quantitative assessment of diet for this little-known species in Australian waters. 


\section{MATERIALS AND METHODS}

Pygmy Sperm Whale occurrence records around Tasmania from 1989-2009 were compiled using data obtained from the Department of Primary Industries, Parks, Water and Environment (DPIPWE) Tasmania, and Tasmanian Museum and Art Gallery (TMAG) records.

On 17 February 2003, two Pygmy Sperm Whales (one juvenile male with total length of $200 \mathrm{~cm}$; and one juvenile female with total length of $215 \mathrm{~cm}$ ) were found dead on Carlton Beach, southeast Tasmania (pl. 1). We classified these individuals as "juveniles" (i.e., not sexually or physically mature) based on Plön (2004: pp. 9-19), who found that for South African Pygmy Sperm Whales, males reach sexual maturity between $241-242 \mathrm{~cm}$ and females at $262 \mathrm{~cm}$. Morphometric data, tissue and organ samples and stomachs were collected from the deceased whales, following the protocols of Geraci \& Lounsbury (2005). Samples were stored at $-20^{\circ} \mathrm{C}$ until analysed.

The stomach contents were subsequently thawed, rinsed through a $1.0 \mathrm{~mm}$ sieve and sorted. Cephalopod remains and parasites, when present, were preserved in $70 \%$ ethanol. Cephalopod beaks were separated from other cephalopod hard-part remains and sorted into upper and lower beaks. The lower beaks were identified to the lowest possible taxonomic level with the aid of cephalopod reference collections held at the Centre d'Etudes Biologiques de Chizé, France (identified by Drs Yves Cherel [YC] and Jose Xavier [JX]); Auckland University of Technology's reference collection of beaks extracted from entire, identified squid and octopus from New Zealand waters (identified by Dr Steve O'Shea [SO] and Emma Betty [EB]); and a cephalopod beak reference collection developed by Evans \& Hindell (2004), currently housed at the University of Tasmania, Hobart. All identified beaks from this study are housed at the Tasmanian Museum and Art Gallery.

To estimate the original size of the cephalopod prey, lower rostral lengths (LRLs) for squid, and lower hood lengths (LHLs) for sepiolids, were measured with digital callipers to the nearest $0.1 \mathrm{~mm}$, and regression equations were used as constructed by Clarke (1980, 1986), Rodhouse et al. (1990), Piatkowski et al. (2001), and Lu \& Ickeringill (2002) (appendix 1). The total number of individuals of each cephalopod species present in a stomach was estimated based on the number of lower beaks, as in many cases the upper beaks were unidentifiable. The relative importance of prey items was quantified by (1) proportion of numerical abundance ( $\%$ Num), the percentage of the total number of prey items represented by a particular prey category; and (2) proportion of reconstructed prey biomass (\%BM), the percentage of reconstructed biomass of prey represented by a particular prey category. The final reconstructed prey weight, which sums the calculated biomass of all ingested individuals, is an underestimation; broken, upper only, or unidentified beaks did not contribute to the total estimate of prey weight.

\section{RESULTS}

Pygmy Sperm Whale stranding events are rare in Tasmania, where this species comprises only $1.4 \%$ of total events and $0.3 \%$ of individuals stranded (DPIPWE unpubl. data). Between 1989 and 2009, a total of six Pygmy Sperm Whales (five events) have stranded along the Tasmanian coastline,
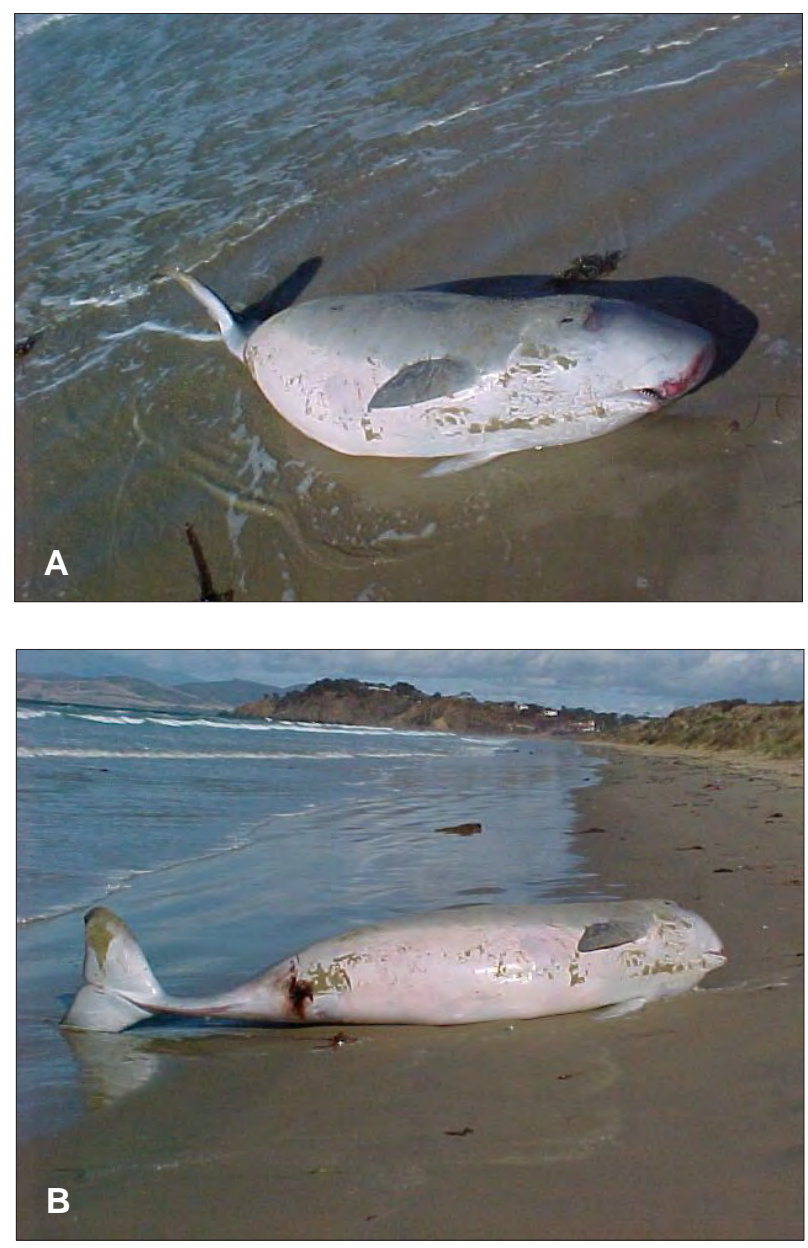

PLATE 1

A, B. Pygmy Sperm Whales that stranded on Carlton Beach, southeast Tasmania on 17 February 2003.

with an additional two historical museum records (table 1; fig. 1). All individuals were dead on discovery, except the individual found alive on Ocean Beach, which was apparently successfully returned to sea. Strandings have been primarily single adults, with two juveniles (male and female) recovered from Carlton Beach in 2003 (pl. 1). There are no records of calves stranding along the Tasmanian coast. No confirmed at-sea sightings of Pygmy Sperm Whales have been reported from Tasmanian waters.

Of the five Pygmy Sperm Whale carcasses recovered, detailed necropsies were performed on only the two individuals recovered from Carlton Beach, where cause of death was unknown. Large numbers of nematodes (species unknown) were present in the stomachs of both animals, and there were numerous squid sucker marks $(5-10 \mathrm{~mm})$ around the heads of both individuals. The stomach of the male contained prey items, whereas the stomach of the female contained only nematodes.

Neither fresh food remains nor bony fish or other contents were recovered from the male individual. The only available dietary information thus results from the analysis of accumulated beaks of cephalopods found throughout the stomach (i.e., forestomach, main stomach, connecting chamber and pyloric stomach). A total of 106 beaks (54 lower and 52 upper beaks) were recovered. The average LRL, mantle length (ML) and biomass (BM) for all squid species, and details of all regression equations describing 


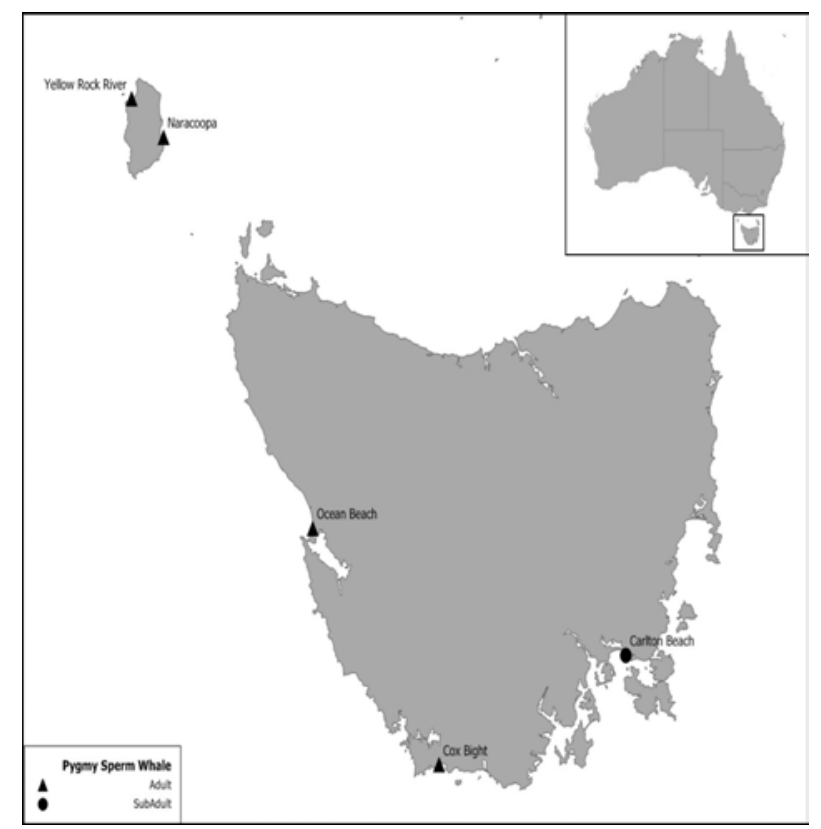

FIG. 1 - Location map of Tasmania showing stranding locations of Pygmy Sperm Whales; including Carlton Beach from where the analysed stomach sample originated.

the relationships of LRL versus ML and BM, calculated and compared in this study are summarised in appendix 1 . These comparisons are important to determine the relative importance of prey items and determine size range (i.e., age class and subsequently life-stage) of prey consumed in order to better understand the foraging ecology of marine predators. The smallest (by BM) cephalopod recovered was a Heteroteuthis sp., estimated at $1.6 \mathrm{~g}(\mathrm{ML}=16 \mathrm{~mm})$. The largest squid recovered was an ommastrephid species with an estimated BM of $544 \mathrm{~g}(\mathrm{ML}=279 \mathrm{~mm})$.

The cephalopod composition of the dietary items consisted of at least 11 species from nine families. Based on the recovered prey, the reconstituted weight of prey remains recovered was equivalent to three kilograms. The most important family according to numerical abundance was Enoploteuthidae (Enoploteuthis sp.) 56\%, followed by Histioteuthidae (Histioteuthis atlantica Hoyle, 1885 and $H$. miranda Berry, 1918) 19\%, Cranchiidae (Cranchia scabra Leach, 1817 and Teuthowenia pellucida Chun, 1910) 9\%, and Ommastrephidae sp. 6\%. Chiroteuthidae (Chiroteuthis veranyi Férussac, 1835) 4\% numerical abundance, was also a prey item of this whale. Low numbers of Brachioteuthidae (Brachioteuthis linkovskyi Lipinski, 2001), Nototeuthidae (Nototeuthis dimegacotyle: Nesis \& Nikitina, 1986), Pyroteuthidae (Pyroteuthis margaritifera Ruppell, 1844), and Sepiolidae (Heteroteuthis sp.) were also recovered (table 2; fig. 2a).

Histioteuthidae comprised the most biomass consumed (30\%), followed by Ommastrephidae (27\%) and Enoploteuthidae (25\%). These three cephalopod families comprised $82 \%$ of all cephalopod biomass consumed (fig. 2b).

Teuthowenia pellucida consisted entirely of juveniles, with mantle lengths ranging from $92-130 \mathrm{~mm}$. Histoteuthis atlantica, Enoploteuthis sp. and Ommastrephidae sp. were all well represented by a mixture of juveniles and adults, with mantle lengths ranging from 19-135 mm, 14-109 $\mathrm{mm}$ and $138-279 \mathrm{~mm}$, respectively. Chiroteuthis veranyi was the only prey that consisted primarily of adults, ranging in mantle lengths from 154-199 mm. One adult Heteroteuthis sp., with a mantle length of $16 \mathrm{~mm}$ was also consumed.

\section{DISCUSSION}

All cephalopod species recovered are commonly found in Tasmanian waters (Evans \& Hindell 2004). An absence of neritic cephalopod species (such as Octopoda [octopuses], Sepiidae [cuttlefish] and Sepioteuthis sp.), compared to a high proportion of midwater oceanic cephalopod species (Enoploteuthidae, Histioteuthidae and Ommastrephidae), indicate that this Pygmy Sperm Whale had recently eaten, at least in part, in deeper offshore mesopelagic waters.

Histioteuthidae was the most important family consumed according to percent biomass, with several juvenile Histioteuthis atlantica $(\mathrm{n}=9)$ and one $H$. miranda of unknown age class identified. Histioteuthids have been

TABLE 1

Summary of all Pygmy Sperm Whale stranding and museum records from Tasmania

\begin{tabular}{|c|c|c|c|c|c|c|}
\hline Date & Location & $\begin{array}{c}\text { Decimal } \\
\text { latitude and } \\
\text { longitude }\end{array}$ & Sex & Age-class & $\begin{array}{c}\text { Total } \\
\text { length } \\
(\mathrm{cm})\end{array}$ & $\begin{array}{l}\text { Status on } \\
\text { discovery }\end{array}$ \\
\hline 1870 (TMAG:A3161) & $\begin{array}{l}\text { Tasmania (no further } \\
\text { locality information) }\end{array}$ & - & unknown & unknown & unknown & Dead \\
\hline 1935 (TMAG:A232) & Not Recorded & - & unknown & unknown & unknown & Dead \\
\hline 10-Sep-89 & Cox Bight & $-43.50,146.21$ & male & adult & 363 & Dead \\
\hline 26-Apr-90 & Naracoopa, King Island & $-39.91,144.13$ & unknown & adult & 345 & Dead \\
\hline 16-Jan-03 & $\begin{array}{l}\text { Ocean Beach, west } \\
\text { coast }\end{array}$ & $-42.14,145.26$ & female & adult & 340 & $\begin{array}{c}\text { Alive and } \\
\text { released }\end{array}$ \\
\hline $\begin{array}{l}\text { 17-Feb-03 } \\
\text { (TMAG:A1757) }\end{array}$ & $\begin{array}{l}\text { Carlton Beach, } \\
\text { southeast coast }\end{array}$ & $-42.87,147.62$ & female & juvenile & 215 & Dead \\
\hline $\begin{array}{l}\text { 17-Feb-03 } \\
\text { (TMAG:A1758) }\end{array}$ & $\begin{array}{l}\text { Carlton Beach, } \\
\text { southeast coast }\end{array}$ & $-42.87,147.62$ & male & juvenile & 200 & Dead \\
\hline 7-Jun-04 & $\begin{array}{l}\text { Phoques Bay, King } \\
\text { Island }\end{array}$ & $-39.69,143.88$ & unknown & adult & 280 & Dead \\
\hline
\end{tabular}

${ }^{1}$ TMAG number. 

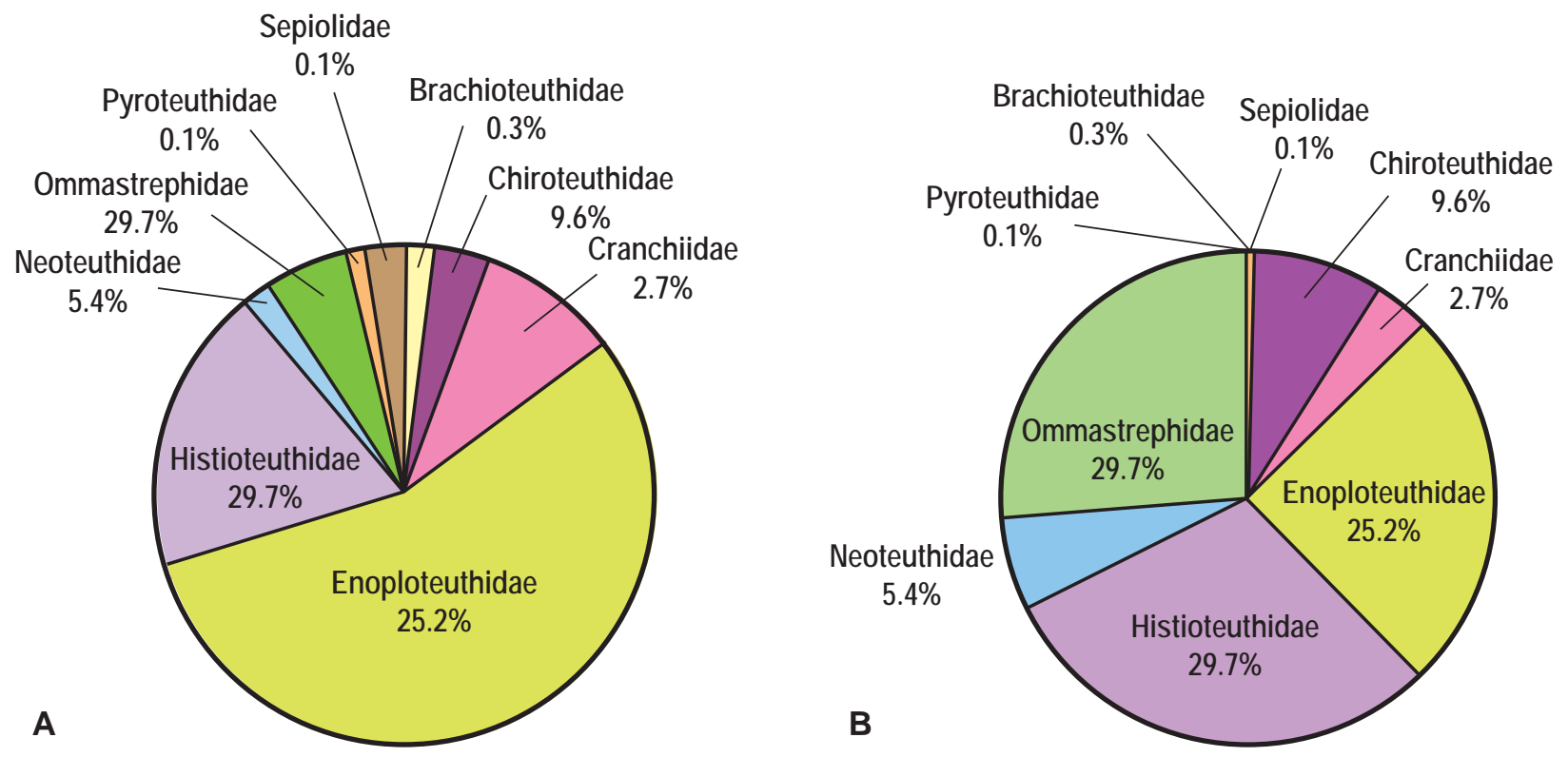

FIG. 2 - (A) \% numerical abundance (\%Num) and (B) \% reconstructed prey mass (\%BM) of cephalopod genera found in the diet of a juvenile Pygmy Sperm Whale stranded at Carlton Beach, southeast Tasmania on 17 February 2003.

TABLE 2

Mean lower rostral length or lower hood length (LRL/LHL), mantle length, and both mean and total wet weight biomass (BM), for all squid species examined

\begin{tabular}{|c|c|c|c|c|c|c|}
\hline Family & Species & $\mathbf{n}^{1}$ & $\begin{array}{l}\text { LRL/LHL } \\
\quad(\mathbf{m m})\end{array}$ & $\begin{array}{l}\text { Mantle length } \\
\quad(\mathrm{mm})\end{array}$ & $\mathbf{B M}(\mathrm{g})$ & Total BM (g) \\
\hline Brachioteuthidae & Brachioteuthis linkovskyi & 1 & 3.4 & 85.1 & 9.8 & 9.8 \\
\hline Chiroteuthidae & Chiroteuthis veranyi & 2 & $\begin{array}{c}6.7 \pm 1.29 \\
(5.8-7.7)\end{array}$ & $\begin{array}{l}176.3 \pm 31.48 \\
(154.0-198.5)\end{array}$ & $\begin{array}{c}141.4 \pm 70.23 \\
(91.8-191.1)\end{array}$ & 282.8 \\
\hline Cranchiidae & Teuthowenia pellucida & 4 & $\begin{array}{l}3.0 \pm 0.68 \\
(2.3-3.6)\end{array}$ & $\begin{array}{l}112.6 \pm 20.5 \\
(91.6-130.2)\end{array}$ & $\begin{array}{l}18.0 \pm 7.60 \\
(10.4-24.5)\end{array}$ & 72.0 \\
\hline Cranchiidae & Cranchia scabra & 1 & 1.4 & 84.1 & 8.6 & 8.6 \\
\hline Enoploteuthidae & Enoploteuthidae sp. & 30 & $\begin{array}{c}3.5 \pm 0.76 \\
(1.0-4.3)\end{array}$ & $\begin{array}{c}85.7 \pm 21.5 \\
(13.6-109.2)\end{array}$ & $\begin{array}{l}26.5 \pm 9.33 \\
(0.87-42.2)\end{array}$ & 740.6 \\
\hline Histioteuthidae & Histioteuthis atlantica & 9 & $\begin{array}{c}2.3 \pm 1.62 \\
(1.1-5.7)\end{array}$ & $\begin{array}{c}48.1 \pm 41.6 \\
(18.8-135.1)\end{array}$ & $\begin{array}{c}63.2 \pm 106.53 \\
(6.1-311.4)\end{array}$ & 568.5 \\
\hline Histioteuthidae & Histioteuthis miranda & 1 & 5 & 122.4 & 303.35 & 303.4 \\
\hline Neoteuthidae & Nototeuthis dimegacotyle & 1 & 3.7 & 197.1 & 54.1 & 158.3 \\
\hline Ommastrephidae & Ommastrephidae (unknown sp.) & 3 & $\begin{array}{c}5.3 \pm 1.70 \\
(3.6-7.0)\end{array}$ & $\begin{array}{l}208.9 \pm 70.31 \\
(138.4-279.0)\end{array}$ & $\begin{array}{c}396.4 \pm 208.03 \\
(249.3-543.5)\end{array}$ & 792.8 \\
\hline Pyroteuthidae & Pyroteuthis margaritifera & 1 & 1 & 32.3 & 2.7 & 2.7 \\
\hline Sepiolidae & Heteroteuthis sp. & 1 & 1.16 & 15.6 & 1.6 & 1.6 \\
\hline Total & & 54 & & & & 2941 \\
\hline
\end{tabular}

${ }^{1}$ All values for which $\mathrm{n}>1$ are expressed as mean \pm SD (range). 
listed as a dominant cephalopod prey in all other Pygmy Sperm Whale diet studies, except those from Taiwan (Wang et al. 2002), and comprised $73 \%$ of the mass consumed by Pygmy Sperm Whales recovered from New Zealand (Beatson 2007). Histioteuthis atlantica has a circumglobal distribution in southern waters and is regularly found in ocean basins, and over shelves and plateaux (Voss et al. 1998). Only H. miranda was found in Pygmy Sperm Whale samples from New Zealand, along with H. macrohista Voss, 1969, Histioteuthis sp. 2, (Beatson 2007), and a single beak later confirmed to be $H$. Type A5 by Horstkotte (2008).

Ommastrephidae was the next most important family consumed according to percent biomass. The unidentified ommastrephids were likely to be Nototodarus gouldi, although Ommastrephes bartramii Lesueur, 1821 and Todarodes sp. are other possible candidates. Nototodarus gouldi McCoy, 1888 is found throughout the year in Australian continental shelf and slope waters (up to 500 $\mathrm{m}$ ) and also appears seasonally in shallow coastal waters, where they are targeted by commercial fisheries (Nottage et al. 2007). Nototodarus gouldi was also found in New Zealand Pygmy Sperm Whale diet samples (7.21\% mass consumed, Beatson 2007).

Enoploteuthidae was the third most important family consumed according to percent biomass. The enoploteuthids in Australian waters are represented by an abundance of small mesopelagic species (Brandt 1983). It remains uncertain which species were recovered in this study; however, they are likely to be Abraliopsis gilchristi Robson, 1924 and Enoploteuthis galaxias Berry, 1918, which are associated with the temperate continental shelf waters of northern New Zealand and South Australia (Tsuchiya
2009). Abraliopsis gilchristi Robson, 1924 and E. galaxias Berry, 1918 are considered mesopelagic boundary species (the pelagic zone extending from $200 \mathrm{~m}$ down to around $800 \mathrm{~m}$ ) (Young 1995).

Most cranchiid species occupy progressively deeper waters as they grow (ontogenetic descent), remaining in near-surface waters until reaching sizes of $50-100 \mathrm{~mm}$ ML (Young \& Mangold 2008). Teuthowenia pellucida occurs only in the southern hemisphere and reaches a maximum size of approximately $200 \mathrm{~mm} \mathrm{ML} \mathrm{(Young} \mathrm{\&}$ Mangold 2008). Its systematics, biogeography and various aspects of its biology have been discussed in detail by Voss (1985). Numerous T. pellucida were also recovered from New Zealand Pygmy Sperm Whale samples (8\% mass consumed, Beatson 2007).

One Nototeuthis dimegacotyle Nesis \& Nikitina, 1986 was recovered. This recently described species was captured between the Southern Subtropical and the Antarctic Polar frontal zones in waters from $30-60 \mathrm{~m}$ and $0-500 \mathrm{~m}$ deep respectively (Nesis \& Nikitina 1992). Nototeuthis dimegacotyle was not recorded from the New Zealand Pygmy Sperm Whale study (Beatson 2007), but has been previously recorded in the diet of Patagonian toothfish (Dissostichus eleginoides) at Crozet (5\% by number) and Kerguelen (rare), Southern Ocean (Cherel et al. 2004).

Chiroteuthidae (juveniles occur near the sea surface, while adults live much deeper: Roper \& Young 1975); Brachioteuthidae (deep-diving with the upper limits of daytime distribution probably at 600-700 m depending on the locality (Roper \& Young 1975)); and Sepiolidae (shallow-living cephalopod family that occurs in the upper few hundred metres during both day and night (Roper \&

TABLE 3

Cephalopod species composition in the diet of the juvenile male Pygmy Sperm Whale stranded at Carlton Beach, southeast Tasmania on 17 February 2003, ranked according to the $\%$ numerical abundance

\begin{tabular}{|c|c|c|c|c|}
\hline Family and species & $\begin{array}{c}\text { Total } \\
\text { number }\end{array}$ & $\%$ Num$^{1}$ & $\mathbf{B M}^{2}$ & $\% \mathrm{BM}^{3}$ \\
\hline Enoploteuthidae (Enoploteuthis sp.) & 30 & 55.6 & 740.6 & 25.2 \\
\hline Histioteuthide & 10 & 18.5 & 871.8 & 29.7 \\
\hline Histioteuthis atlantica & 9 & 16.7 & 568.5 & 19.3 \\
\hline Histioteuthis miranda & 1 & 1.9 & 303.4 & 10.3 \\
\hline Cranchiidae & 5 & 9.3 & 80.6 & 2.7 \\
\hline Cranchia scabra & 1 & 1.9 & 8.6 & 0.3 \\
\hline Teuthowenia pellucida & 4 & 7.4 & 72.0 & 2.5 \\
\hline Ommastrephidae (unknown sp.). & 3 & 5.6 & 792.8 & 27.0 \\
\hline Chiroteuthidae (Chiroteuthis veranyi) & 2 & 3.7 & 282.8 & 9.6 \\
\hline Neoteuthidae (Nototeuthis dimegacotyle) & 1 & 1.9 & 158.3 & 5.4 \\
\hline Brachioteuthidae (Brachioteuthislinkovskyi) & 1 & 1.9 & 9.8 & 0.3 \\
\hline Pyroteuthidae (Pyroteuthis margaritifera) & 1 & 1.9 & 2.7 & 0.1 \\
\hline Sepiolidae (Heteroteuthis sp.) & 1 & 1.9 & 1.6 & 0.1 \\
\hline Total lower beaks & 54 & & 2941 & \\
\hline Total upper beaks & 52 & & & \\
\hline
\end{tabular}

$1 \%$ Num = proportion of numerical abundance

$2 \mathrm{BM}$ (grams) = reconstructed prey biomass

$3 \% \mathrm{BM}=$ proportion of reconstructed prey biomass 
Young 1975)), were the least important families identified in the Tasmanian Pygmy Sperm Whales' diet. Although chiroteuthids were significant components of the diet in the New Zealand study, Brachioteuthis and Heteroteuthis were also recorded in low numbers (Beatson 2007).

Our finding that the stomach of the Pygmy Sperm Whale from Carlton Beach contained primarily mesopelagic cephalopod species is broadly consistent with the New Zealand study (Beatson 2007), and other studies on Pygmy Sperm Whale diet from throughout their range, such as waters surrounding the Azores (Martins et al. 1985), Brazil (Secchi et al. 1994, Santos \& Haimovici 2001, 2002), the Canary Islands (Hernandez-Garcia \& Martin 1996, Fernandez et al. 2009), the Caribbean (Cardona-Maldonado \& Mignucci-Giannoni 1999), South Africa (Ross 1979, Klages et al. 1989, Sekiguchi et al. 1992, Plön et al. 1999), the Atlantic coasts of the United States and Canada (Raun et al. 1970, Candela 1987, McAlpine et al. 1997, Santos et al. 2006), the Pacific coasts of the United States and Mexico (Scheffer and Slipp 1948, Eliason \& Houck 1986, Vidal et al. 1987), the Hawaiian Archipelago (West et al. 2009), and Taiwan (Wang et al. 2002).

Acknowledging the limitations of diet studies (Bigg \& Fawcett 1985, Jobling \& Breiby 1986, Pierce \& Boyle 1991, Gannon et al. 1997) and the problems and biases that act to favour the underestimation of the relative importance of fish and the overestimation of cephalopods (Gannon et al. 1997), it remains evident that cephalopods appear to be the major component of Pygmy Sperm Whale diet in southern Australian waters. More stomach samples, including some stomachs with undigested components are required for further studies. Although this study represents only a single individual, it provides an insight into a component of the foraging ecology of this little-known species, and a basis for comparison to both past and future studies in Australia and worldwide. Further Pygmy Sperm Whale diet studies from around Australia are required to determine additional target prey in Australian waters, and allow more comprehensive comparisons with worldwide studies.

Despite the seemingly high frequency of Pygmy Sperm Whale strandings in some Australian states, there remains very little published or unpublished information on diet, life history or comparative studies based on collected tissue samples (if collected at all). Inferring from the stranding record, Pygmy Sperm Whales are rarely encountered in the Tasmanian region, possibly in contrast to other areas of Australia (e.g., New South Wales) and New Zealand (where it is one of the most commonly stranded cetacean species) (Beatson 2007). Regional differences in species distribution should be considered in management initiatives.

Pelagic cephalopods are a major component of Pygmy Sperm Whale diet, and these are also affected by targeted fisheries (e.g., N. gouldi) and trawling activities around Australia (which are known to destroy the gelatinous egg masses of many pelagic cephalopod prey species (O'Shea et al. 2004, Beatson 2007). The importance of cephalopods in the diets of keystone predators (e.g., cetaceans, pinnipeds and seabirds) in the Tasmanian region, and Australiawide, should be carefully considered in the sustainable management of the commercial cephalopod fishery.

\section{ACKNOWLEDGEMENTS}

Many thanks to DPIPWE Marine Mammal Conservation program staff for their assistance with data and sample collection from stranded individuals. Thanks also to the Tasmanian Museum and Art Gallery (Katherine Medlock and Belinda Bauer) for providing information on Tasmanian museum records of Pygmy Sperm Whales, and the Mount Pleasant Laboratories for undertaking the necropsies of the two stranded individuals.

Particular thanks to Dr Jose Xavier and Dr Steve O'Shea for their much-appreciated assistance with cephalopod beak identification. Thanks to Rupert Davies, Mathew Golding and Christine Jackson for their assistance in measuring the cephalopod beaks. Thanks to Kris Carlyon for helping to prepare the location maps.

Many thanks to the State and Territory government agencies for providing information on stranded Pygmy Sperm Whales, in particular Strandnet (Jenny Greenland, Jaylene Flint and Justin Meager) for Queensland records; the Department of Land Resource Management (Ray Chatto and Carol Palmer) for Northern Territory records; the Nature Protection Branch, Department of Parks and Wildlife (Douglas Coughran) for Western Australian records; South Australian Museum (Catherine Kemper) for South Australian records; and Department of Sustainability and Environment (Kirsty Greengrass) for Victorian records.

Particular thanks to two anonymous reviewers and the editor Margaret Davies for their constructive comments on earlier versions of the manuscript.

This project was funded by the Princess Melikoff Trust.

\section{REFERENCES}

Beatson, E. 2007: The diet of pygmy sperm whales, Kogia breviceps, stranded in New Zealand: implications for conservation. Reviews in Fish Biology and Fisheries 17: 295-303.

Bigg, M.A. \& Fawcett, I. 1985: Two biases in diet determination of northern fur seals (Callorhinus ursinus). In Beddington, J.R., Beverton, R.J.H. \&. Lavigne, D.M. (eds): Marine Mammals and Fisheries. George, Allen and Unwin, London: 284-291.

Brandt, S.B. 1983: Pelagic squid associations with a warm-core eddy of the East Australian Current. Australian Journal of Marine and Freshwater Research 34: 573-585.

Candela, S.M. 1987: Cephalopod prey of pygmy and dwarf sperm whales (Kogia breviceps and K. simus) stranded in Florida and Georgia. Abstract. Seventh biennial conference on the biology of marine mammals, December 5-7, 1987. Miami, Florida, USA, p.9.

Cardona-Maldonado, M.A. \& Mignucci-Giannoni, A.A. 1999: Pygmy and dwarf sperm whales in Puerto Rico and the Virgin Islands, with a review of Kogia in the Caribbean. Caribbean Journal of Science 35: 29-37.

Cherel, Y., Duhamel, G. \& Gasco, N. 2004: Cephalopod fauna of subantarctic islands: new information from predators. Marine Ecology Progress Series. 266: 143-156.

Clarke, M.R. 1980: Cephalopoda in the diet of sperm whales of the Southern Hemisphere and their bearing on sperm whale biology. Discovery Reports 37: 1-324.

Clarke, M.R. 1986: Handbook for the Identification of Cephalopod Beaks. Oxford University Press, Oxford: 273 pp.

Department of Environment Water Heritage and the Arts (DEWHA). 2011: Sightings and strandings of the pygmy sperm whale. http://data.aad.gov.au/aadc/whales/ species_sightings.cfm?taxon_id=57. Downloaded on 6 January 2011. 
Eliason, J.J. \& Houck, W.J. 1986: Notes on the biology of a gravid pygmy sperm whale (Kogia breviceps) from California. Cetology 51: 1-5.

Evans, K. \& Hindell, M.A. 2004. The diet of sperm whales (Physeter macrocephalus) in southern Australian waters. ICES Journal of Marine Science 61: 1313-1329.

Fernandez, R., Santos, M.B., Carrillo, M., Tejedor, M. \& Pierce, G.J. 2009: Stomach contents of cetaceans stranded in the Canary Islands 1996-2006. Journal of the Marine Biological Association of the United Kingdom 89(5): 873-883.

Gannon, D.P., Read, A.J., Craddock, J.E., Fristrup, K.M. \& Nicolas, J.R. 1997: Feeding ecology of long-finned pilot whales Globicephala melas in the western North Atlantic. Marine Ecology Progress Series 148: 1-10.

Geraci, J.R. \& Lounsbury, V.J. 2005: Marine Mammals Ashore: A Field Guide for Strandings, Second Edition. National Aquarium in Baltimore, Baltimore, MD: $371 \mathrm{pp}$.

Groom, C.J. \& Coughran, D.K. 2012: Three decades of cetacean strandings in Western Australia: 1981 to 2010. Journal of the Royal Society of Western Australia 95: 63-76.

Hale, H.M. 1947: The pigmy (sic) sperm whale (Kogia breviceps, Blainville) on South Australian Coasts. Records of the South Australian Museum 8: 531-546.

Hernandez-Garcia, V. \& Martin, V. 1996: Food habits of the pygmy sperm whale Kogia breviceps (de Blainville, 1838) stranded in the Canary Islands. In Proceedings of the second symposium Fauna and Flora of the Atlantic Islands, las Palmas de Gran Canaria, Spain, 12-16 February 1996: 202 pp.

Hortskotte, J. 2008: The systematics and ecological role of Histioteuthis (Cephalopoda: Histioteuthidae) in New Zealand waters. Unpublished Diploma thesis, LeibnizInstitut für Meereswissenschaften an der Universität Kiel, Germany: 255 pp.

Jobling, M. \& Breiby, A. 1986: The use and abuse of fish otoliths in studies of feeding habits of marine piscivores. Sarsia 71: 265-274.

Kemper, C.M. \& Ling, J.K. 1991: Whale strandings in south Australia (1881-1989). Transactions of the Royal Society of South Australia 115(1): 37-52.

Klages, N., Cockcroft, V.G. \& Best, P.B. 1989: Stomach contents of pygmy Kogia breviceps and dwarf K. simus sperm whales stranded on South African beaches. Abstract. $8^{\text {th }}$ Biennial Conference on the Biology of Marine Mammals, Dec 7-11, 1989, Pacific Grove, CA: 35 pp.

Lu, C.C. \& Ickeringill, R. 2002: Cephalopod beak identification and biomass estimation techniques: tools for dietary studies of southern Australian finfishes. Museum Victoria Science Reports 6: 1-65.

McAlpine, D.F. 2002: Pygmy and dwarf sperm whales (Kogia breviceps and Kogia sima). In Perrin, W.F., Wursig, B. \& Thewissen, J.G.M. (eds): Encyclopedia of Marine Mammals. Academic Press, San Diego, CA: 1007-1009.

McAlpine, D.F., Murison, L.D. \& Hoberg, E.P. 1997: New records for the pygmy sperm whale, Kogia breviceps (Physeteridae) from Atlantic Canada with notes on diet and parasites. Marine Mammal Science 13: 701-704.

Martins, H.R., Clarke, M.R., Reiner, F. \& Santos, R.S. 1985. A pygmy sperm whale, Kogia breviceps (Blainville 1838) (Cetacea: Odontoceti) stranded on Faial Island, Azores, with notes on cephalopod beaks in stomach. Arquipelago 6: 63-70.

Nesis, K.N. \& Nikitina, I.V. 1992: New genus and species of squid of the family Neoteuthidae (Cephalopoda, Oegopsida) from the South-eastern part of the Pacific Ocean. Zoologichesky Zhurnal, 65(2): 290-294

Nottage, J.D., West, R.J., Montgomery, S.S. \& Graham, K. 2007: Cephalopod diversity in commercial fisheries landings of New South Wales, Australia. Review of Fish Biology and Fisheries 17: 271-281.

O'Shea, S., Bolstad, K.S. \& Ritchie, P.A. 2004. First records of egg masses of Nototodarus gouldi McCoy 1888
(Cephalopoda: Ommastrephidae), with comments on egg-mass susceptibility to damage by fisheries trawl. New Zealand Journal of Zoology 31: 161-166.

Piatkowski, U., Pierce, G.J. \& Morais da Cunha, M. 2001: Impact of cephalopods in the food chain and their interaction with the environment and fisheries: an overview. Fisheries Research 52: 5-10.

Pierce, G.J. \& Boyle, P.R. 1991: A review of methods for diet analysis in piscivorous marine mammals. Oceanography and Marine Biology 29: 409-486.

Plön, S.E.E. 2004: The status and natural history of pygmy (Kogia breviceps) and dwarf (K. sima) sperm whales off Southern Africa. Unpublished $\mathrm{PhD}$ thesis, Rhodes University, South Africa.

Plön, S.E.E., Bernard, R.T.F., Klages, N.T. \& Cockcroft, V.G. 1999: Stomach content analysis of pygmy and dwarf sperm whales and its ecological implications: is there niche partitioning? European Research on Cetaceans 13. Proceedings of the $13^{\text {th }}$ Annual Conference of the European Cetacean Society, Valencia, Spain, 5-8 April 1999.

Raun, G.G., Hoese, H.D. \& Moselely, F. 1970: Pygmy sperm whales, genus Kogia, on the Texas coast. Texas Journal of Science 21: 269-274.

Rodhouse, P.G., Prince, P.A., Clarke, M.R. \& Murray, A.W.A. 1990: Cephalopod prey of the grey-headed albatross Diomedea chrysostoma. Marine Biology 3: 353-362.

Roper, C.F.E. \& Young, R.E. 1975: Vertical distribution of pelagic cephalopods. Smithsonian Contributions to Zoology 209: 1-51.

Ross, G.J.B. 1979: Records of pygmy and dwarf sperm whales. Genus Kogia, from southern Africa, with biological notes and some comparisons. Annals of the Cape Provincial Museums (Natural History) 11: 259-327.

Santos, M.B., Pierce, G.J., Lopez, A., Reid, R.J., Ridoux, V. \& Mente, E. 2006: Pygmy sperm whales Kogia breviceps in the Northeast Atlantic: new information on stomach contents and strandings. Marine Mammal Science 22: 600-616.

Scheffer, V.B. \& Slipp, J.W. 1948: The whales and dolphins of Washington State with a key to the cetaceans of the west coast of North America. American Midland Naturalist 39: 257-337.

Secchi, E.R., Campolom, M.B. \& Moller, L. 1994: Notes sobre o encalhe de dois cachalotes pigmeus Kogia breviceps NA costa sul do Rio Grande do sul-Brasil. In Oporto JA (ed): Anales de la Reunion de trabajo de Especialistas en mamiferos Aquaticos de America del sur 12-15 Nov 1990, Chile: 244-262.

Sekiguchi, K., Klages, N.T.W. \& Best, P.B. 1992: Comparative analysis of the diets of smaller odontocete cetaceans along the coast of southern Africa. Southern African Journal of Marine Science 12: 843-861.

Tsuchiya, K. 2009: Enoploteuthis galaxias Berry 1918. Version 23 July 2009 (under construction). http://tolweb.org/ Enoploteuthis_galaxias/19707/2009.07.23 in The Tree of Life Web Project, http://tolweb.org/

Vidal, O., Findley, L.T., Turk, P.J. \& Boyer, E. 1987: Recent records of pygmy sperm whales in the Gulf of California, Mexico. Marine Mammal Science 3(4): 354-356.

Voss, N.A. 1985: Systematics, biology and biogeography of the cranchiid cephalopod genus Teuthowenia (Oegopsida). Bulletin of Marine Science 36: 1-85.

Voss, N.A., Nesis, K.N. \& Rodhouse, P.G. 1998: The cephalopod family Histioteuthidae (Oegopsida): Systematics, biology, and biogeography. Smithson Contributions to Zoology 586(2): 293-372.

Wang, M.C., Walker, W.A., Shao, K.T. \& Chou, L.S. 2002: Comparative analysis of the diets of pygmy sperm whales and dwarf sperm whales in Taiwanese waters. Acta Zoologica Taiwanica 13(2): 53-62.

West, K.L., Walker, W.A., Baird, R.W., White, W., Levine, G., 
Brown, E. \& Schofield, D. 2009: Diet of pygmy sperm whales (Kogia breviceps) in the Hawaiian Archipelago. Marine Mammal Science 25: 931-943.

Xavier, J.C. \& Cherel, Y. 2009: Cephalopod Beak Guide for the Southern Ocean. British Antarctic Survey, Cambridge, UK: 129 pp.

Young, R.E. 1995: Aspects of the natural history of pelagic cephalopods of the Hawaiian mesopelagic-boundary region. Pacific Science 49:143-155.
Young, R.E. \& Mangold, K.M. 2008: Cranchiidae Prosch, 1847. Bathyscaphoid squids. Version 22 April 2008. http://tolweb. org/Cranchiidae/19411/2008.04.22 in The Tree of Life Web Project, http://tolweb.org/

(accepted 5 November 2013)

APPENDIX 1

Regression equations used for calculation of mantle length (ML) and reconstructed biomass (BM)

\begin{tabular}{|c|c|c|c|c|}
\hline Family & Species & Author & LRL versus ML (n) & LRL versus BM (n) \\
\hline Brachioteuthidae & Brachioteuthis linkovskyi & $\begin{array}{l}\text { Clarke (1986)/Xavier \& } \\
\text { Cherel (2009) }\end{array}$ & $\begin{array}{l}M L=16.31 \pm \\
20.18(L R L)(n=11)\end{array}$ & $\begin{array}{l}\mathrm{BM}=0.55 \pm 1.41 \ln (\mathrm{LRL}) \\
(\mathrm{n}=11)\end{array}$ \\
\hline Chiroteuthidae & Chiroteuthis veranyi & $\begin{array}{l}\text { Clarke (1980)/Xavier \& } \\
\text { Cherel (2009) }\end{array}$ & $\begin{array}{l}\mathrm{ML}=11.4 \pm \\
24.46(\mathrm{LRL})(\mathrm{n}=23)\end{array}$ & $\begin{array}{l}\mathrm{BM}=-0.241 \pm 2.7 \ln (\mathrm{LRL}) \\
(\mathrm{n}=14)\end{array}$ \\
\hline Cranchiidae & Cranchia scabra & Clarke (1986) & $\begin{array}{l}\mathrm{ML}=17.8 \pm \\
48.72(\mathrm{LRL})(\mathrm{n}=45)\end{array}$ & $\begin{array}{l}\mathrm{BM}=1.58 \pm 1.85 \ln (\mathrm{LRL}) \\
(\mathrm{n}=40)\end{array}$ \\
\hline Cranchiidae & Teuthowenia pellucida & $\begin{array}{l}\text { Rodhouse et al. (1990)/ } \\
\text { Xavier \& Cherel (2009) }\end{array}$ & $\begin{array}{l}\mathrm{ML}=22.27 \pm 29.90 \\
(\mathrm{LRL})(\mathrm{n}=41)\end{array}$ & $\begin{array}{l}\mathrm{BM}=0.71 \pm 1.94 \ln (\mathrm{LRL}) \\
(\mathrm{n}=41)\end{array}$ \\
\hline Enoploteuthidae & Enoploteuthis sp. & Lu \& Ickeringill 2002 & $\begin{array}{l}M L=-13.04 \pm 34.56 \\
(L R L)(n=45)\end{array}$ & $\begin{array}{l}\mathrm{BM}=0.32 \pm 3.00 \ln (\mathrm{LRL}) \\
(\mathrm{n}=45)\end{array}$ \\
\hline Histioteuthidae & Histioteuthis atlantica & $\begin{array}{l}\text { Lu \& Ickeringill 2002/ } \\
\text { Xavier \& Cherel (2009) }\end{array}$ & $\begin{array}{l}M L=-10.42 \pm \\
25.66(L R L)(n=21)\end{array}$ & $\begin{array}{l}\mathrm{BM}=1.49 \pm 2.45 \ln (\mathrm{LRL}) \\
(\mathrm{n}=19\end{array}$ \\
\hline Histioteuthidae & Histioteuthis miranda & $\begin{array}{l}\text { Clarke (1986)/Xavier \& } \\
\text { Cherel (2009) }\end{array}$ & $\begin{array}{l}M L=-7.0 \pm \\
25.82(L R L)(n=54)\end{array}$ & $\begin{array}{l}\mathrm{BM}=1.783 \pm 2.44 \\
\ln (\mathrm{LRL})(\mathrm{n}=53)\end{array}$ \\
\hline Neoteuthidae & $\begin{array}{l}\text { Nototeuthis dimegacotyle } \\
\text { (based on Alluroteuthis } \\
\text { antarcticus which is } \\
\text { larger than Neoteuthis } \\
\text { dimegacotyle) }\end{array}$ & Piatkowski et al. 2001 & $\begin{array}{l}\mathrm{ML}=-4.301 \pm \\
34.99(\mathrm{LRL})(\mathrm{n}=22)\end{array}$ & $\begin{array}{l}\mathrm{BM}=1.229 \pm 2.944 \\
\ln (\mathrm{LRL})(\mathrm{n}=22)\end{array}$ \\
\hline Ommastrephidae & $\begin{array}{l}\text { Ommastrephidae } \\
\text { (unknown sp.) }\end{array}$ & $\begin{array}{l}\text { Clarke (1986)/Xavier \& } \\
\text { Cherel (2009) }\end{array}$ & $\begin{array}{l}\mathrm{ML}=-11.3 \pm 41.36 \\
\mathrm{LRL}(\mathrm{n}=83)\end{array}$ & $\begin{array}{l}\mathrm{BM}=0.783 \pm 2.83 \\
\ln (\mathrm{LRL})(\mathrm{n}=83)\end{array}$ \\
\hline Pyrotheuthidae & $\begin{array}{l}\text { Pyroteuthis } \\
\text { margaritifera }\end{array}$ & Lu \& Ickeringill 2002 & $\begin{array}{l}M L=5.26 \pm \\
26.73(L R L)(n=25)\end{array}$ & $\begin{array}{l}\mathrm{BM}=0.97 \pm 2.70 \ln (\mathrm{LRL}) \\
(\mathrm{n}=25)\end{array}$ \\
\hline Sepiolidae & Heteroteuthis sp. & Lu \& Ickeringill 2002 & $\begin{array}{l}\text { ML }=-3.73 \pm 16.66 \\
\text { LHL }(n=25)\end{array}$ & $\begin{array}{l}\mathrm{BM}=0.01 \pm 3.12 \ln (\mathrm{LHL}) \\
(\mathrm{n}=25)\end{array}$ \\
\hline
\end{tabular}

